ARTICLE

DOI: $10.1038 / s 41467-017-00557-w$

\title{
Mining drives extensive deforestation in the Brazilian Amazon
}

\author{
Laura J. Sonter ${ }^{1,2,3,4}$, Diego Herrera ${ }^{1,2,5}$, Damian J. Barrett ${ }^{6}$, Gillian L. Galford ${ }^{1,2}$, Chris J. Moran ${ }^{7}$ \\ \& Britaldo S. Soares-Filho 8
}

Mining poses significant and potentially underestimated risks to tropical forests worldwide. In Brazil's Amazon, mining drives deforestation far beyond operational lease boundaries, yet the full extent of these impacts is unknown and thus neglected in environmental licensing. Here we quantify mining-induced deforestation and investigate the aspects of mining operations, which most likely contribute. We find mining significantly increased Amazon forest loss up to $70 \mathrm{~km}$ beyond mining lease boundaries, causing $11,670 \mathrm{~km}^{2}$ of deforestation between 2005 and 2015. This extent represents 9\% of all Amazon forest loss during this time and 12 times more deforestation than occurred within mining leases alone. Pathways leading to such impacts include mining infrastructure establishment, urban expansion to support a growing workforce, and development of mineral commodity supply chains. Mining-induced deforestation is not unique to Brazil; to mitigate adverse impacts of mining and conserve tropical forests globally, environmental assessments and licensing must considered both on- and off-lease sources of deforestation.

\footnotetext{
${ }^{1}$ Gund Institute for Environment, University of Vermont, 617 Main Street, Burlington, VT 05405, USA. ${ }^{2}$ Rubenstein School of Environment and Natural Resources, University of Vermont, Burlington, VT 05405, USA. ${ }^{3}$ School of Earth and Environmental Sciences, The University of Queensland, Brisbane, Qld 4072, Australia. ${ }^{4}$ Centre for Biodiversity \& Conservation Science, The University of Queensland, Brisbane, Qld 4072, Australia. ${ }^{5}$ Environmental Defense Fund, Washington, DC 20009, USA. ${ }^{6}$ Energy Flagship, Commonwealth Scientific and Industrial Research Organisation (CSIRO), Canberra, ACT 2601, Australia. ${ }^{7}$ Curtin University, Perth, WA 6102, Australia. ${ }^{8}$ Centro de Sensoriamento Remoto, Universidade Federal de Minas Gerais, Belo Horizonte, MG 31270-901, Brazil. Correspondence and requests for materials should be addressed to L.J.S. (email: I.sonter@uq.edu.au)
} 
educing tropical deforestation to conserve biodiversity and regulate climate is a globally significant goal $^{1-3}$, yet deforestation rates remain high ${ }^{4}$. Even in Brazil, where policy interventions and economic conditions have reduced annual deforestation rates by $80 \%{ }^{5},>127,000 \mathrm{~km}^{2}$ of forests have been cleared since $2005^{6}$. At present, priority is given to management of spatially extensive drivers of deforestation (e.g., urban population growth and crop production ${ }^{7,8}$ ). Demand for minerals also poses significant risks 9,10 , particularly where mineral resources and biodiverse old-growth forests co-exist ${ }^{11}$ in developing countries that seek revenue from mining but lack regulatory oversight and enforcement capability ${ }^{12}$.

Mining causes deforestation both within and beyond lease boundaries. Within leases, forests are cleared for mineral extraction, processing, and infrastructure development ${ }^{13,} 14$. However, off-lease impacts are potentially more extensive and their pathways more complex ${ }^{9}, 15-18$. Deforestation may extend substantial distances $(>10 \mathrm{~km})$ beyond lease boundaries $9,17,18$, due to the combined effects of land use displacement ${ }^{19}$, urban expansion ${ }^{20}$, development of commodity supply chains ${ }^{21}$, and concerns over mine waste discharge $e^{22}$ and spills ${ }^{23}$. It is essential to understand and mitigate mining-induced deforestation if tropical forests are to be conserved ${ }^{18}$, yet the full extent of these impacts (on- and off-lease) have not been quantified heretofore.

We focus on Brazil's Amazon forest (Fig. 1), the world's largest remaining tropical forest ${ }^{4}$ and a region undergoing increased mining activity ${ }^{16,23}$. Throughout Brazil, mining leases, concessions, and exploration permits cover 1.65 million $\mathrm{km}^{2}$ of land, of which $60 \%$ is located in the Amazon forest ${ }^{24}$. Mineral production contributed $4 \%$ to Brazil's gross domestic product in $2011^{25}$ and this value is projected to increase fourfold by $2030^{26}$. Approval of new mines and expansion of existing projects require environmental licenses. However, current impact assessments do not systematically consider off-lease, indirect or cumulative sources of deforestation ${ }^{16}$, and proposed legislative changes will expedite approval of strategic projects $(654 / 2,015)^{27}$, remove the power of environmental agencies to suspend operations based on environmental impacts (PEC-65) ${ }^{27-30}$, and enable extraction within protected and indigenous areas (PL3682/2012; PL1610/ $1996)^{16,31}$.

To quantify mining-induced deforestation, we use satellite data and propensity score matching, a method for identifying causal affects ${ }^{32-36}$. Deforestation $(2005-15)^{6}$ is assessed within 'treatment' areas: large operational mining leases $(n=50$; Fig. 1 and Table 1$)^{24}$ and their surrounding buffers (concentric zones $10 \mathrm{~km}$ wide up to $100 \mathrm{~km}$ from leases). A control for each treatment is selected from areas farther than $100 \mathrm{~km}$ from leases (but within Brazil's Amazon forest) accounting for spatial variables known to explain the distribution of mining leases ${ }^{13}$ and correlate with deforestation ${ }^{37}$. The difference in forest loss between treatments and these controls is thus the deforestation attributable to mining. Our primary findings are supplemented with two exploratory analyses. First, pathways of mining-induced deforestation are investigated by comparing a range of socioeconomic conditions between municipalities that contain mines with those that do not. Second, mining-induced deforestation at the local scale is explored utilizing two case study mines (Carajás and Trombetas). Our results reveal extensive deforestation, significant up to $70 \mathrm{~km}$ from lease boundaries, caused by large scale industrial mining operations in Brazil's Amazon forest.

\section{Results}

Extent of mining-induced deforestation. Mining caused deforestation within leases. These areas contained $6,880 \mathrm{~km}^{2}$ of forests in 2005 , of which $14 \%\left(983 \mathrm{~km}^{2}\right)$ were cleared by 2015 (Table 1). Mining also caused deforestation off-lease. Deforestation within buffers was significantly greater than expected up to $70 \mathrm{~km}$ from leases (Fig. 2 and Table 2; $t$-test; $P<0.05)$. Off-lease, forests within the $0-10 \mathrm{~km}$ and $40-50 \mathrm{~km}$ buffers experienced the highest rates of mining-induced deforestation (4.4\%) (Table 2). The total area impacted by mining (lease areas, $0-70 \mathrm{~km}$ buffers) contained $337,690 \mathrm{~km}^{2}$ of forests in 2005 and underwent $37,830 \mathrm{~km}^{2}$ of clearing by 2015 (Table 3). Of this total deforestation, $11,670 \mathrm{~km}^{2}(31 \%)$ was induced by mining (Table 3 ), as indicated by differences in

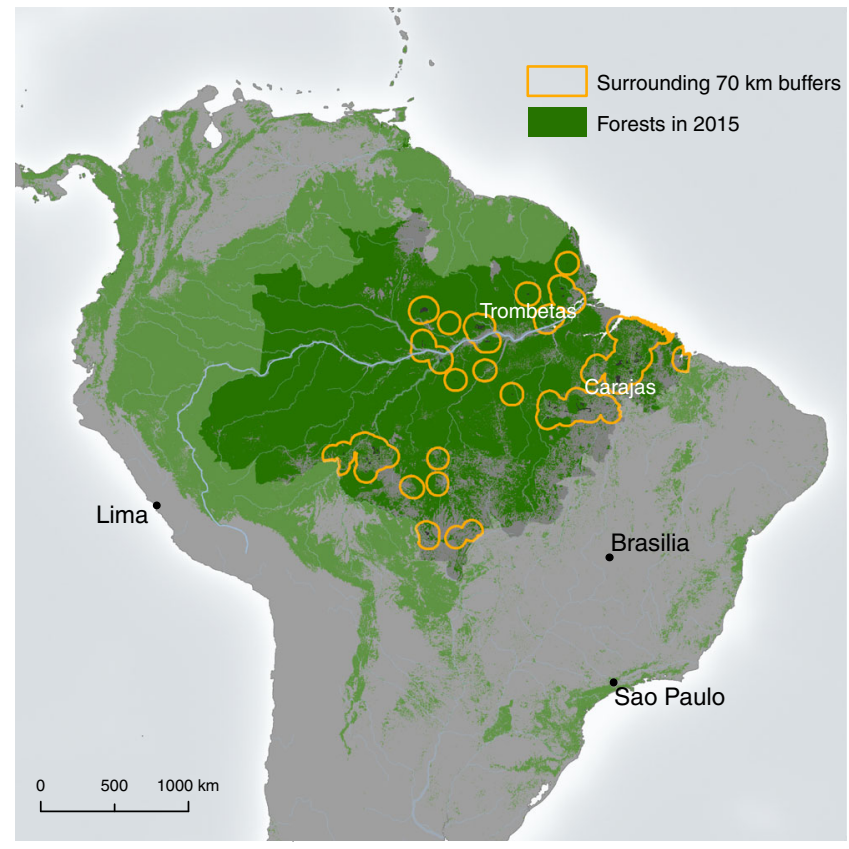

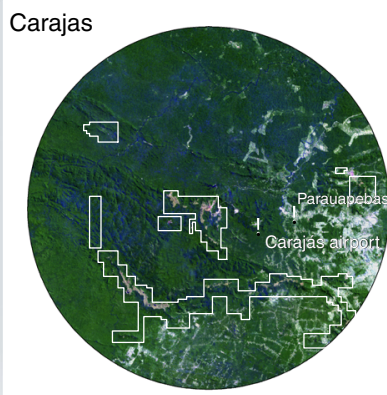

1985

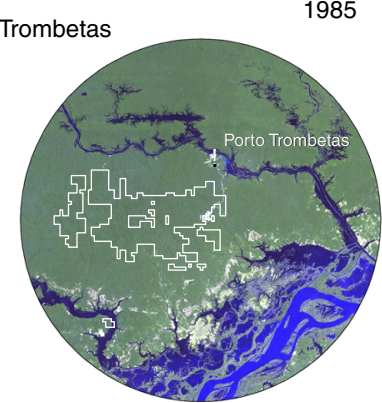

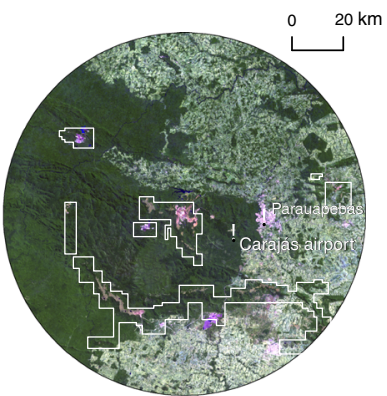

2015

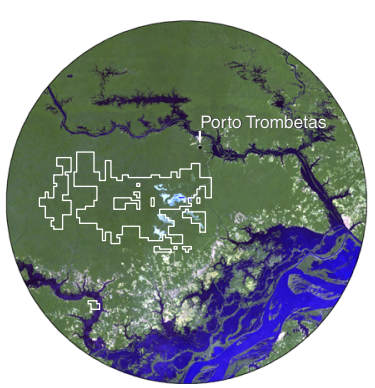

Fig. 1 Mining in Brazil's Amazon forest. Left: distribution of mining leases and forests in 2015 ${ }^{4}$. Right: case study mining operations. Mining leases are shown as white polygons overlying Landsat TM imagery for 1985 and 2015. Landsat pixel-based cloud-free mosaic, bands 3, 2, 1. Green areas indicate forests, bright white areas indicate non-forested ground, and blue areas are water 


\begin{tabular}{|c|c|c|c|c|c|c|c|c|c|}
\hline \multirow[t]{2}{*}{ State } & \multirow[t]{2}{*}{ Major commodity } & \multirow[t]{2}{*}{ Year } & \multirow[t]{2}{*}{ Area $\left(\mathbf{k m}^{2}\right)$} & \multicolumn{2}{|c|}{$\begin{array}{l}\text { Forest cover } \\
2005\left(\mathrm{~km}^{2}\right)\end{array}$} & \multicolumn{2}{|c|}{$\begin{array}{l}\text { Deforestation } \\
\text { 2005-2015 }\left(\mathrm{km}^{2}\right)\end{array}$} & \multicolumn{2}{|c|}{$\begin{array}{l}\text { Deforestation } \\
\text { 2005-2015 (\%) }\end{array}$} \\
\hline & & & & ML & 0-70 km & ML & $0-70 \mathrm{~km}$ & ML & $0-70 \mathrm{~km}$ \\
\hline AM & Iron ore & 1960 & 16 & 16 & 13,430 & 0 & 52 & 0.0 & 0.4 \\
\hline RO & Tin & 1961 & 150 & 137 & 12,398 & 9 & 1,826 & 6.6 & 14.7 \\
\hline PA & Iron ore & 1969 & 162 & 80 & 1,706 & 32 & 560 & 40.0 & 32.8 \\
\hline PA & Clay & 1970 & 28 & 0 & 2,704 & 0 & 835 & & 30.9 \\
\hline RO & Tin & 1970 & 96 & 28 & 5,681 & 18 & 365 & 64.3 & 6.4 \\
\hline$A P$ & Bauxite/Kaolin & 1971 & 248 & 116 & 12,987 & 25 & 474 & 21.6 & 3.6 \\
\hline PA & Bauxite & 1971 & 798 & 465 & 7,714 & 56 & 1,172 & 12.0 & 15.2 \\
\hline RO & Tin & 1971 & 950 & 688 & 9,544 & 62 & 2,524 & 9.0 & 26.4 \\
\hline AM & Limestone & 1975 & 35 & 35 & 13,644 & 0 & 43 & 0.0 & 0.3 \\
\hline PA & Tin & 1975 & 46 & 14 & 3,648 & 7 & 84 & 50.0 & 2.3 \\
\hline PA & Tin & 1976 & 255 & 124 & 12,120 & 61 & 2,472 & 49.2 & 20.4 \\
\hline PA & Bauxite & 1977 & 1,233 & 833 & 11,775 & 133 & 1,880 & 16.0 & 16.0 \\
\hline MT & Dolomite & 1977 & 52 & 12 & 2,496 & 6 & 640 & 50.0 & 25.6 \\
\hline $\mathrm{AP}$ & Gold & 1978 & 24 & 4 & 7,228 & 3 & 37 & 75.0 & 0.5 \\
\hline $\mathrm{AP}$ & Gold & 1978 & 148 & 146 & 13,988 & 2 & 16 & 1.4 & 0.1 \\
\hline$A P$ & Clay & 1978 & 11 & 0 & 2,612 & 0 & 55 & & 2.1 \\
\hline AM & Tin & 1978 & 974 & 879 & 18,928 & 29 & 46 & 3.3 & 0.2 \\
\hline MA & Gold & 1978 & 82 & 24 & 1,754 & 5 & 439 & 20.8 & 25.0 \\
\hline PA & Tin & 1979 & 154 & 83 & 4,441 & 40 & 128 & 48.2 & 2.9 \\
\hline MT & Gold & 1979 & 416 & 106 & 4,604 & 33 & 778 & 31.1 & 16.9 \\
\hline $\mathrm{AP}$ & Iron ore & 1980 & 100 & 71 & 3,285 & 8 & 67 & 11.3 & 2.0 \\
\hline MT & Gold & 1982 & 71 & 4 & 848 & 1 & 215 & 25.0 & 25.4 \\
\hline RO & Tin & 1987 & 326 & 83 & 4,601 & 53 & 1,840 & 63.9 & 40.0 \\
\hline AM & Kaolin & 1988 & 260 & 112 & 13,716 & 27 & 1,122 & 24.1 & 8.2 \\
\hline PA & Aluminium & 1991 & 230 & 129 & 6,797 & 10 & 378 & 7.8 & 5.6 \\
\hline MT & Diamond & 1991 & 88 & 33 & 11,053 & 16 & 1,105 & 48.5 & 10.0 \\
\hline $\mathrm{AP}$ & Iron ore & 1992 & 210 & 159 & 11,437 & 18 & 276 & 11.3 & 2.4 \\
\hline PA & Kaolin & 1993 & 18 & 6 & 1,641 & 2 & 476 & 33.3 & 29.0 \\
\hline PA & Silica & 1995 & 12 & 2 & 2,430 & 1 & 652 & 50.0 & 26.8 \\
\hline PA & Nickel & 1996 & 148 & 9 & 3,856 & 3 & 131 & 33.3 & 3.4 \\
\hline PA & Silica & 2000 & 22 & 1 & 1,353 & 1 & 636 & 100.0 & 47.0 \\
\hline RO & Tin/Granite & 2002 & 33 & 9 & 4,605 & 8 & 665 & 88.9 & 14.4 \\
\hline MA & Granite & 2003 & 12 & 7 & 2,900 & 0 & 806 & 0.0 & 27.8 \\
\hline RO & Clay & 2005 & 16 & 0 & 13,892 & 0 & 1,823 & & 13.1 \\
\hline \multirow[t]{3}{*}{$\mathrm{RO}$} & Manganese & 2005 & 30 & 4 & 9,987 & 0 & 993 & 0.0 & 9.9 \\
\hline & & Column averages: & 237 & 138 & 7,048 & 20 & 748 & 33 & 16 \\
\hline & & Column totals: & 11,850 & 6,920 & 352,381 & 983 & 37,388 & & \\
\hline
\end{tabular}

deforestation rates between treatment areas and their matched controls.

Pathways leading to mining-induced deforestation. Socioeconomic conditions differed between municipalities that contained mining leases and those that did not (Fig. 3). Municipalities with mines had a greater number of registered companies $(W=33,438, P<0.001)$, employees per company
$(W=32,594, P<0.001)$, and salary per employee $(W=36,716$, $P<0.001)$. Municipalities with mines had a greater population in $2010(W=35,197, P<0.001)$ and population growth between 2000 and $2010 \quad(W=34,668, \quad P<0.001)$. Municipalities with mines also had larger permanent cropped areas $(W=26,870$, $P<0.001)$ and greater deforestation for fuelwood $(W=19,783$, $P<0.001)$ but not for roundwood $(W=21,581, P=0.311)$ or charcoal production $(W=11,839, P=0.502)$. 


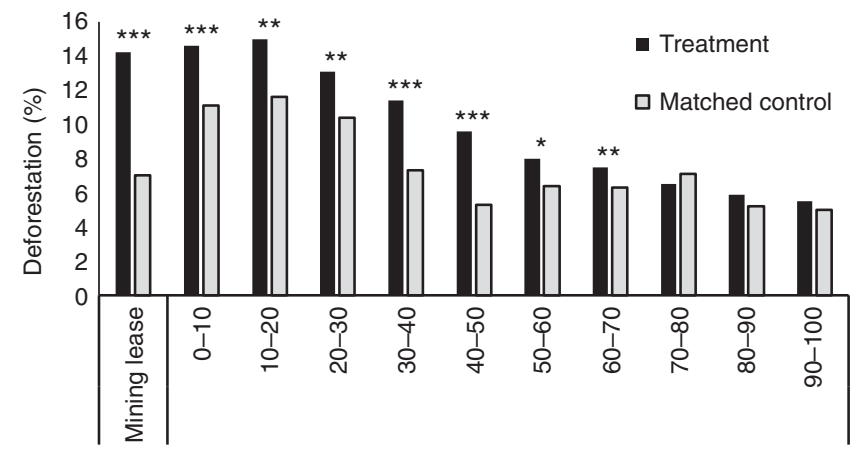

Fig. 2 Deforestation rates within treatments and matched controls. Differences between treatments and their matched controls is the deforestation attributeable to mining. Stars denote significant differences (t-test; ${ }^{\star \star \star} P<0.001,{ }^{\star \star} P<0.01$, and ${ }^{\star} P<0.05$; see Table 2 )

Evidence from case study mining operations. Carajás, owned by the Brazilian company Vale, is the world's largest iron ore operation. In 2007, a US $\$ 2.48$ billion expansion was approved to establish new mining pits and processing infrastructure, clearing forests within leases. An influx of people to support growing operations led to further deforestation, expanding nearby towns and facilities. Mined ore and processed materials are transported via a company-established 890 -km-long railway to the deep-water port (Ponta da Madeira) in São Luís, Maranhão. In addition, iron ore mining creates demand for charcoal to produce pig iron, driving expansion of tree plantations and native forest loss ${ }^{21}$.

Trombetas is Brazil's largest bauxite producer, owned by Mineração Rio do Norte (MRN) and others (Rio Tinto, Vale, South32, CBA, Alcoa, and Norsk Hydro). As with Carajás, factors contributing to deforestation include infrastructure establishment (for mineral processing and transportation) and urban development. For example, bauxite is transported from Trombetas by barge to the Alunorte refinery in the town of Barcarena, where the Porto Trombetas urban area was developed in 1975 to support the growing workforce and catalyze economic development ${ }^{38}$. In addition, off-lease positive environmental changes were evident. For example, the company rehabilitated the Batata Lake and helped establish the Saraca-Taaquera National Forest and Trombetas Biological Reserve to prevent further forest loss and environmental degradation.

\section{Discussion}

Mining caused extensive deforestation in Brazil's Amazon forest between 2005 and 2015. Deforestation within mining leases was triple the average Amazon clearing rate, caused by the direct consequences of mining. However, mining indirectly caused more extensive deforestation off-lease. By controlling for other spatial determinants of deforestation, we found that these impacts extend $70 \mathrm{~km}$ from mining leases-a distance much farther than previously suggested ${ }^{17}$ - to affect an area containing $18 \%$ of Amazon forests in 2005. In total, mining-induced deforestation has been 12 times greater than that occurring within mining leases alone and caused 9\% of all deforestation within Brazil's Amazon forest since 2005. To capture the full extent of these impacts, the assessment of new mines and expansion of existing projects must consider both on- and off-lease sources of deforestation.

Mitigating off-lease impacts of mining requires understanding the pathways through which this deforestation occurs. In Brazil's Amazon forest, impact pathways may include mining infrastructure establishment and associated secondary forest clearing (such as that associated with new roads), urban expansion to support a growing workforce and indirect economic activities stimulated by mining. Another pathway is the development of commodity supply chains (e.g., charcoal for iron and steel manufacturing $\left.{ }^{21}\right)$. Specifically, socio-economic statistics ${ }^{39-42}$ and Wilcoxon's rank-sum tests (Fig. 3) suggest mining operations are associated with increased population growth, greater economic activity, and production of fuelwood and food. Although fuelwood demand is rarely a primary driver of Amazon deforestation, it may represent an intermediate transition between forest and other more profitable land uses.

Mining-induced deforestation was also evident locally, as illustrated in two case study operations from Pará (Fig. 1). Carajás and Trombetas are two of the largest and best-known industrial mining operations in Brazil. Both were established in the 1970s and illustrate long-term ( \pm 40 years; Fig. 1 ) impacts of mining on forests within and beyond leases. We found both operations induced deforestation within $70 \mathrm{~km}$ of their leases (Fig. 1), due to urban development and infrastructure establishment for mineral processing and transportation. These operations, as well as other mines analyzed in this study (Table 1), also show that variation exists among them. For some, their impacts extend $>70 \mathrm{~km}$ from lease boundaries (such as deforestation due to establishing the 892-km-long railway connecting Carajás to the Ponta da Madeira Port in São Luís) and emerge only after a long period of operation. Case study mines support the findings of this paper, but do not illustrate all possible pathways and consequences of mining-induced deforestation.

The extent and pathways of mining-induced deforestation may also vary among regions ${ }^{18}$. Here we found that mining increased deforestation in Brazil's Amazon forest, although some companies also invest in conservation (e.g., Alcoa's efforts at Juruti). However, in the country's largest iron ore mining region, the Quadrilátero Ferrífero (QF) in Minas Gerais (located outside the Amazon forest), mining companies reduced off-lease deforestation by conserving land adjacent to leases ${ }^{43}, 44$. Mining, deforestation trajectories, and environmental policies differ between these regions, which may explain differing outcomes. Mines in Brazil's Amazon were often established in previously inaccessible forests near known deforestation frontiers (Fig. 1), which may have drawn people to new economic opportunities and catalyzed further clearing. In comparison, mines in QF compete with, rather than create opportunities for, other land users. Environmental regulation of mining in Minas Gerais is also stricter than those in the Amazon forest. Minas Gerais has additional requirements to avoid, mitigate and monitor impacts and enforcement in this state is effective ${ }^{45}$.

Mining poses significant risks to tropical forests worldwide; yet, rarely is mineral production considered a significant driver of extensive deforestation. Our results reveal important implications for forest conservation in Brazil. Current government policies do not consider the full extent of mining-induced deforestation ${ }^{16}$ and proposed legislative changes further reduce assessment and mitigation requirements ${ }^{25,27-31}$. Mining-induced deforestation is not unique to Brazil ${ }^{22}$. To conserve tropical forests and mitigate the adverse impacts of mining, assessment, and environmental licensing processes must consider both on- and off-lease sources of deforestation.

\section{Methods}

Deforestation and spatial determinants. We defined Brazil's Amazon forest $\left(\sim 3.1\right.$ million $\left.\mathrm{km}^{2}\right)$ to include all municipalities intersecting the Amazonian biome $^{46}$. Deforestation in the period 2005-15 (specifically, August 2004-July 2015) was quantified within mining leases and buffer zones using PRODES ${ }^{6}$ time series data resampled to $1 \mathrm{~km}$ resolution (nearest neighbor method). Mining leases ( $n=50$; Table 1$)$ were limited to large operations ( $>10 \mathrm{ha})$, other than quarries, which had been approved prior to $2005^{24}$. Although some lag time likely exists between lease approval and initial deforestation, this lag is ignored here as it is unlikely longer than 1 year, given that sites often establish site infrastructure prior 
Table 2 Deforestation rates within treatments and their matched controls

\begin{tabular}{lllllll}
\multirow{2}{*}{ Treatment } & \multicolumn{2}{l}{ Deforestation rates (2005-2015) } & Bias adjusted estimator & Matched controls (n) & Placebo test (t stat) \\
\cline { 2 - 4 } & Treatment & Matched control & Difference & & \\
\cline { 1 - 3 } Mining lease & 0.142 & 0.070 & 0.072 & $0.078^{\star \star \star}$ & 329 & -1.36 \\
$0-10 \mathrm{~km}$ & 0.146 & 0.111 & 0.036 & $0.044^{\star \star \star}$ & 70 & -0.22 \\
$10-20 \mathrm{~km}$ & 0.150 & 0.116 & 0.034 & $0.041^{\star \star}$ & 91 & 0.82 \\
$20-30 \mathrm{~km}$ & 0.131 & 0.104 & 0.027 & $0.026^{\star \star}$ & 107 & 1.09 \\
$30-40 \mathrm{~km}$ & 0.114 & 0.073 & 0.041 & $0.042^{\star \star \star}$ & 90 & 0.67 \\
$40-50 \mathrm{~km}$ & 0.096 & 0.053 & 0.043 & $0.044^{\star \star \star}$ & 100 & -0.19 \\
$50-60 \mathrm{~km}$ & 0.080 & 0.064 & 0.016 & $0.020^{\star}$ & 100 & 1.33 \\
$60-70 \mathrm{~km}$ & 0.075 & 0.063 & 0.012 & $0.021^{\star \star}$ & 107 & 0.72 \\
$70-80 \mathrm{~km}$ & 0.065 & 0.071 & -0.006 & 0.002 & 105 & 0.57 \\
$80-90 \mathrm{~km}$ & 0.059 & 0.052 & 0.007 & 0.008 & 125 & -0.18 \\
$90-100 \mathrm{~km}$ & 0.055 & 0.050 & 0.005 & 0.005 & 0.00
\end{tabular}

'Difference' indicates mining-induced deforestation, using the propensity score matching estimator; it represents the difference in deforestation between treatments and their matched controls. The bias adjusted estimator is the mining-induced deforestation when controlling for any remaining post-matching bias (see Methods). 'Matched controls ( $n$ )' are the number of unique control observations used in 'matching with replacement'. Placebo tests compare matched controls and a placebo set of controls (see Methods); all treatments pass Placebo tests ( $P>0.05$ )

Stars denote significant differences: ${ }^{* \star *} P<0.001,{ }^{\star \star} P<0.01$, and ${ }^{\star} P<0.05$

Table 3 Summary statistics for mining leases, surrounding buffers, unmatched controls farther than $>100 \mathrm{~km}$ from mining leases, and the total impact area

\begin{tabular}{|c|c|c|c|c|c|c|c|c|c|c|c|c|c|}
\hline & \multirow{2}{*}{$\begin{array}{l}\text { Mining } \\
\text { leases }\end{array}$} & \multicolumn{10}{|c|}{ Surrounding buffers $(\mathbf{k m})$} & \multirow[t]{2}{*}{$>100 \mathrm{~km}$} & \multirow[t]{2}{*}{ Impact area } \\
\hline & & $0-10$ & $10-20$ & 20-30 & $30-40$ & $40-50$ & $50-60$ & $60-70$ & $70-80$ & $80-90$ & 90-100 & & \\
\hline Land area & 11,848 & 59,069 & 904,59 & 150,317 & 190,610 & 257,429 & 304,332 & 378,685 & 430,882 & 506,611 & 556,179 & $1,709,020$ & $1,442,749$ \\
\hline Forests 2005 & 6,882 & 26,738 & 34,727 & 42,737 & 48,908 & 54,152 & 59,243 & 64,303 & 68,108 & 68,993 & 66,158 & $1,289,961$ & 337,690 \\
\hline Deforestation & 983 & 4,044 & 5,417 & 5,808 & 5,817 & 5,459 & 5,105 & 5,192 & 4,786 & 4,379 & 3,971 & 76,049 & 37,825 \\
\hline $\begin{array}{l}\text { Mining-induced deforestation } \\
\text { Covariates }\end{array}$ & 983 & 1,176 & 1,424 & 1,111 & 2,054 & 2,383 & 1,185 & 1,350 & 0 & 0 & 0 & 0 & 11,666 \\
\hline Protected areas & 0.378 & 0.384 & 0.417 & 0.465 & 0.480 & 0.531 & 0.584 & 0.607 & 0.614 & 0.631 & 0.640 & 0.554 & \\
\hline Agricultural suitability & 0.117 & 0.189 & 0.226 & 0.271 & 0.275 & 0.287 & 0.308 & 0.316 & 0.317 & 0.342 & 0.335 & 0.494 & \\
\hline Distance to rivers & 3.312 & 3.023 & 2.857 & 2.849 & 2.844 & 2.864 & 2.884 & 2.908 & 2.914 & 2.939 & 2.956 & 3.093 & \\
\hline Elevation & 2.610 & 2.316 & 2.215 & 2.227 & 2.190 & 2.171 & 2.172 & 2.160 & 2.168 & 2.174 & 2.241 & 2.242 & \\
\hline Distance to roads & 4.775 & 4.505 & 4.781 & 4.989 & 5.106 & 5.226 & 5.376 & 5.467 & 5.548 & 5.530 & 5.503 & 5.997 & \\
\hline Amazonas & 0.149 & 0.149 & 0.178 & 0.209 & 0.232 & 0.252 & 0.256 & 0.257 & 0.264 & 0.256 & 0.249 & 0.516 & \\
\hline Rondonia & 0.186 & 0.186 & 0.188 & 0.171 & 0.164 & 0.159 & 0.154 & 0.139 & 0.107 & 0.086 & 0.067 & 0.020 & \\
\hline Tocantins & 0.002 & 0.003 & 0.002 & 0.001 & 0.003 & 0.003 & 0.002 & 0.003 & 0.003 & 0.003 & 0.002 & 0.000 & \\
\hline Maranhao & 0.022 & 0.022 & 0.016 & 0.029 & 0.036 & 0.035 & 0.030 & 0.027 & 0.020 & 0.017 & 0.017 & 0.004 & \\
\hline Para & 0.531 & 0.532 & 0.464 & 0.433 & 0.402 & 0.387 & 0.381 & 0.383 & 0.391 & 0.428 & 0.456 & 0.235 & \\
\hline Amapa & 0.065 & 0.065 & 0.082 & 0.078 & 0.080 & 0.081 & 0.086 & 0.090 & 0.085 & 0.073 & 0.064 & 0.010 & \\
\hline
\end{tabular}

The total impact area represents mining leases and 0-70 km surrounding buffers. Top four rows show total land area $\left(\mathrm{km}^{2}\right)$, forest extent in $2005\left(\mathrm{~km}^{2}\right)$, deforestation between 2005 and $2015\left(\mathrm{~km}^{2}\right)$, and mining induced deforestation $\left(\mathrm{km}^{2}\right)$. Bottom rows show mean covariate values

to final approval. Mining leases were grouped spatially (within $20 \mathrm{~km}$ of one another) and by operation to avoid overlap. Nine $10-\mathrm{km}$-wide concentric buffers were constructed around each lease using ArcGIS version 10.1. We used a $10 \mathrm{~km}$ buffer width since impacts of mining have previously been suggested to occur at this distance from lease boundaries ${ }^{17}$.

We obtained data on spatial variables previously found to explain the location of mining operations in Brazil ${ }^{13}$ and correlate with Amazon deforestation ${ }^{37,47}$. These included the following: protected areas (indigenous lands, strictly protected areas, sustainable use areas, and military areas); agricultural suitability (an indicator of suitability of soil and terrain for mechanized crops $^{48}$ ); distance to major rivers; distance to major roads; elevation; and state boundaries. Categorical variables (protected areas and agricultural aptitude) are shown in Supplementary Fig. 1. Continuous variables (distance to roads, distance to rivers, and elevation) were categorized to ranges that had been found to significantly impact deforestation, using the Weights of Evidence method (Supplementary Fig. 2). Categorical variables were not auto-correlated $(<0.3 \text { Pearson's correlation })^{37,47}$ and we assumed no correlation in their errors. Table 3 summarizes land area, forest extent in 2005, deforestation during 2005-15, and spatial variables within mining leases, buffers, and Brazil's Amazon forest.

Propensity score matching. Mining leases are biased relative to other non-mining spatial determinants of deforestation. For example, forests within mining leases were less frequently designated as protected areas than forests throughout the rest of Brazil's Amazon (Table 3). As a result, deforestation observed within surrounding buffers not only reflects the impacts of mining, but also the influence of these other determinants. To control for this observable bias, and quantify mining-induced deforestation, we used propensity score matching. This method has been previously used to quantify the causal effect of protected areas on deforestation within ${ }^{32}$ and beyond $\mathrm{d}^{33-35}$ their boundaries. Analysis was conducted in Stata 14 (psmatch2) ${ }^{49}$.
For each observation $\left(1 \mathrm{~km}^{2}\right.$ grid cell) within a treatment area (mining leases and surrounding buffers), we selected control observations from areas farther than $100 \mathrm{~km}$ from leases but within Brazil's Amazon forest. The 'matching with replacement' method was applied, which matches all treatment observations with a control observation, permitting re-use of controls from $1,757,870$ potential observations. We used probit models to generate propensity scores ${ }^{36}$ and select control observations that were similar to their treatment's spatial variables and thus deforestation probability (Supplementary Table 1). To remove any remaining post-matching bias between treatments and controls, we calculated a bias-adjusted estimator by regressing deforestation on the dummy variable for mining leases and all other spatial variables used in the model, using the matched sample (treatment and control observations) (Table 2).

Our method assumes that controlled spatial variables were unaffected by mining and thus represent pre-mining conditions. This was reasonable to assume for exogenous variables (agricultural suitability, elevation, states, and distance to rivers). However, two endogenous variables (distance to roads and protected areas) may affect, or be affected by, mining leases. Forests within buffers were closer to roads and contained fewer protected areas than forests outside buffers (Table 3). If some roads were established to support mining operations, and some protected areas strategically sited away from mineral-rich land, accounting for these effects would increase deforestation within matched controls (Fig. 2). However, we considered the likelihood of these effects to be insignificant. Our road map represents major paved roads and highways ${ }^{37,47}$, rather than small-scale or mining roads, and decisions to establish new protected areas have only recently considered the location of mining leases ${ }^{22}$. It was not possible to only control for protected areas established prior to mining operations, since $90 \%$ of mines were established before the earliest protected areas $(<1970$; Table 1$)$. However removing all observations (treatment and control) from our analysis that fell within protected areas increases estimates of mining-induced deforestation to $20,544 \mathrm{~km}^{2}$, representing $16 \%$ of all $2005-15$ Amazon forest loss (Supplementary Table 2). 

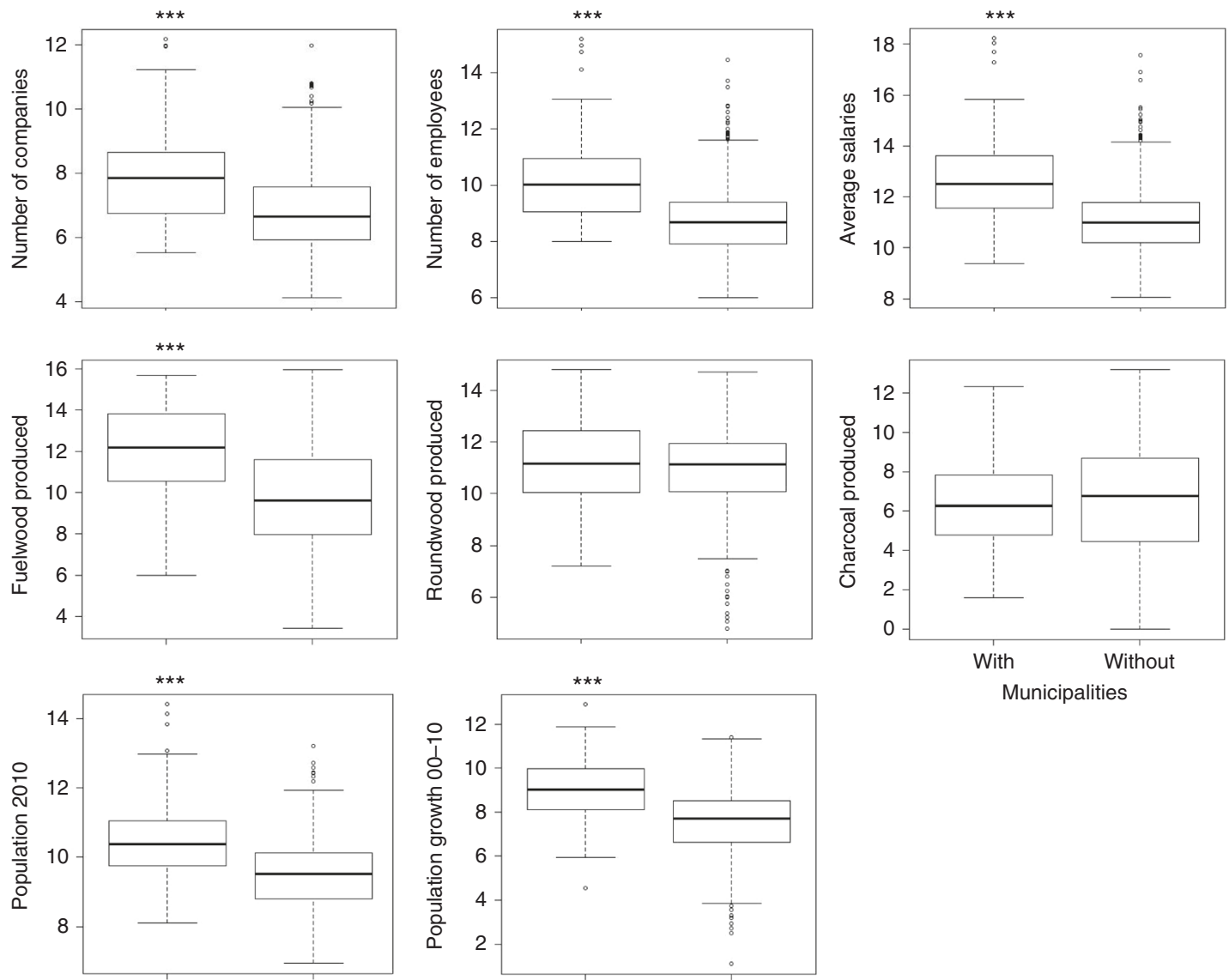

Municipalities
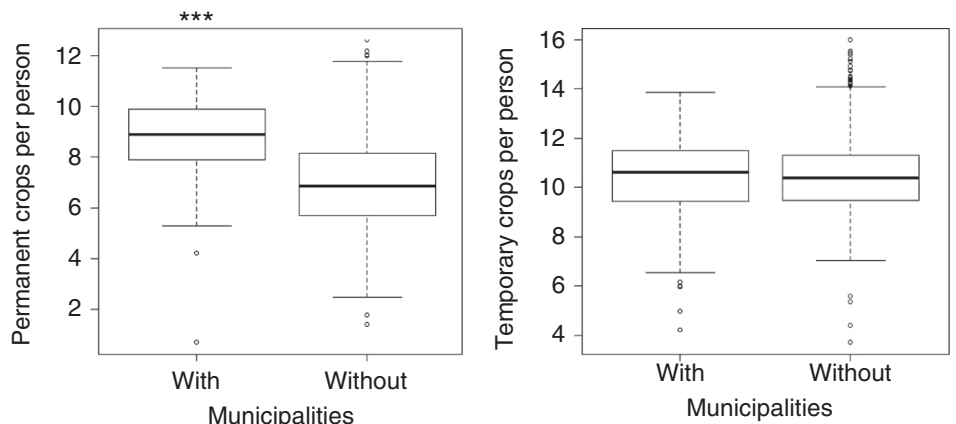

Fig. 3 Socio-economic variables of municipalities with mining leases verses those without. All response variables have been log-transformed. Stars denote significant differences (Wilcoxon's rank-sum tests; ${ }^{\star \star \star} P<0.001$ ). Note: the quantity of fuelwood, roundwood, and charcoal produced (second row) excludes silviculture. All data sets are described in Supplementary Table 3

We also assume that our matching method controlled for all significant determinants of deforestation. To assess the degree to which our results are sensitive to unobserved heterogeneity we conducted Placebo tests ${ }^{50}$. The placebo group was defined as our matched controls and we matched each of these observations to a unique control observation (matching without replacement). If robust, differences in deforestation between placebos and controls should be insignificant ${ }^{50}$, which was true for all treatments (Table 2). To test model robustness, we repeated all analyses using two alternative matching methods: 'matching without replacement' (each treatment observation has a unique control observation) and 'matching with calipers' (which sets a threshold propensity score to select control observations). Alternative methods reduced less bias than 'matching with replacement' and three buffers $(0-30 \mathrm{~km})$ did not pass placebo tests (Supplementary Table 2); thus, we do not report these results in the main paper. However, our main conclusions for both alternative methods-mining-induced deforestation extends beyond lease boundaries and causes more deforestation off-lease than on-lease.

Pathways leading to mining-induced deforestation. We obtained municipalityscale data on economic activities, population dynamics, and wood and food production (Supplementary Table 3 ). We hypothesized an indirect association of each of these variables with mining operations. For each variable, we compared municipalities with $(n=71)$ and without mining leases $(n=653)$, using non-parametric Wilcoxon's rank-sum tests with continuity correction in $\mathrm{R}$ version 3.0. Municipalities contained mining operations if they intersected one of the 50 mining leases assessed in this study (Fig. 1 and Table 1).

Data availability. All data supporting the findings of this study are either publically available online via the referenced source, or can be obtained directly from the corresponding author upon request.

Received: 29 September 2016 Accepted: 10 July 2017

Published online: 18 October 2017

\section{References}

1. ICSU, ISSC. Review of the Sustainable Development Goals: The Science Perspective. International Council for Science (ICSU) (2015).

2. Millennium Ecosystem Assessment. Ecosystems and Human Well-Being: Current State and Trends. Island (2005). 
3. Foley, J. A. et al. Global consequences of land use. Science 309, 570-574 (2005).

4. Hansen, M. C. et al. High-resolution global maps of 21 st-century forest cover change. Science 342, 850-853 (2013).

5. Nepstad, D. et al. The end of deforestation in the Brazilian Amazon. Science 326, 1350-1351 (2009).

6. INPE. Monitoring of the Brazilian Amazonian Forest by Satellite, 2000-2015. Instituto Nacional de Pesquisas Especias, (2016).

7. Lambin, E. F., Geist, H. J. \& Lepers, E. Dynamics of land-use and land-cover change in tropical regions. Annu. Rev. Environ. Resour. 28, 205-241 (2003).

8. DeFries, R. S., Rudel, T., Uriarte, M. \& Hansen, M. Deforestation driven by urban population growth and agricultural trade in the twenty-first century. Nat. Geosci. 3, 178-181 (2010)

9. Butt, N. et al. Biodiversity risks from fossil fuel extraction. Science 342, 425-426 (2013).

10. Patapov, P. et al. The last frontiers of wilderness: tracking loss of intact forest landscapes from 2000 to 2013. Sci. Adv,. 3, e1600821 (2017).

11. Murguía, D. I., Bringezu, S. \& Schaldach, R. Global direct pressures on biodiversity by large-scale metal mining: Spatial distribution and implications for conservation. J. Environ. Manag. 180, 409-420 (2016).

12. Laurance, W. F. et al. Averting biodiversity collapse in tropical forest protected areas. Nature 489, 290-294 (2012).

13. Sonter, L. J., Barrett, D. J., Soares-Filho, B. S. \& Moran, C. J. Global demand for steel drives extensive land-use change in Brazil's Iron Quadrangle. Glob. Environ. Change 26, 63-72 (2014).

14. Alvarez-Berríos, N. L. \& Aide, T. M. Global demand for gold is another threat for tropical forests. Environ. Res. Lett. 10, 014006 (2015)

15. Bridge, G. Contested terrain: mining and the environment. Annu. Rev. Environ. Resour. 29, 205-259 (2004).

16. Ferreira, J. et al. Brazil's environmental leadership at risk. Science 346, 706-707 (2014).

17. Duran, A. P., Rauch, J. \& Gaston, K. J. Global spatial coincidence between protected areas and metal mining activities. Biol. Conserv. 160, 272-278 (2013).

18. Sonter, L. J., Moran, C. J., Barrett, D. J. \& Soares-Filho, B. S. Processes of land use change in mining regions. J. Clean. Prod. 84, 494-501 (2014).

19. Schueler, V., Kuemmerle, T. \& Schroder, H. Impacts of surface gold mining on land use systems in Western Ghana. Ambio 40, 528-539 (2011).

20. Mwitwa, J., German, L., Muimba-Kankolongo, A. \& Puntodewo, A. Governance and sustainability challenges in landscapes shaped by mining: mining-forestry linkages and impacts in the Copper Belt of Zambia and the DR Congo. Forest Policy Econ. 25, 19-30 (2012).

21. Sonter, L. J., Barrett, D. J., Moran, C. J. \& Soares-Filho, B. S. Carbon emissions due to deforestation for the production of charcoal used in Brazil's steel industry. Nat. Clim. Change 5, 359-363 (2015).

22. Edwards, D. P. et al. Mining and the African environment. Conserv. Lett. 7, 302-311 (2014).

23. Edwards, D. P. \& Laurance, W. F. Preventing tropical mining disasters. Science 350, 1482-1482 (2015).

24. DNPM. Processos Minerarios: Sistema de Informações Geográficas da Mineração (SIGMINE) Departamento Nacional de Produção Mineral (DNPM), (2012).

25. USGS. Minerals Yearbook, Brazil. U.S. Geological Survey (2000-2010).

26. MME. Plano Nacional de Mineração 2030: Geologia, Mineração e Transformação Mineral. Ministério de Minas e Energia (2011).

27. Fearnside, P. M. Brazilian politics threaten environmental policies. Science 353, 746-748 (2016).

28. Wade, L. Brazilian crisis threatens science and environment. Science 352 1044-1044 (2016)

29. Almeida, R. M., Lovejoy, T. E. \& Roland, F. Brazil's Amazon conservation in peril. Science 353, 228-229 (2016).

30. Tollefson, J. Political upheaval threatens Brazil's environmental protections. Nature 539, 147-148 (2016)

31. El Bizri, H. R., Macedo, J. C. B., Paglia, A. P. \& Morcatty, T. Q. Mining undermining Brazil's environment. Science 353, 228-228 (2016).

32. Pfaff, A., Robalino, J., Herrera, D. \& Sandoval, C. Protected areas' impacts on brazilian amazon deforestation: examining conservation-development interactions to inform planning. PLoS ONE 10, e0129460 (2015).

33. Robalino, J., Pfaff, A., Willalobos, L. Heterogeneous local spillovers from protected areas in Costa Rica. J. Assoc. Environ. Resourc. Econ. 4, 795-820 (2015).

34. Andam, K. S., Ferraro, P. J., Pfaff, A., Sanchez-Azofeifa, G. A. \& Robalino, J. A. Measuring the effectiveness of protected area networks in reducing deforestation. Proceedings of the National Academy of Sciences 105, 16089-16094 (2008).

35. Herrera, D. Protected Areas' Deforestation Spillovers and Two Critical Underlying Mechanisms: An Empirical Exploration for the Brazilian Amazon. Duke University (2015).
36. Rosenbaum, P. \& Rubin, D. B. The central role of the propensity score in observational studies for causal effects. Biometrika 70, 41-55 (1983).

37. Soares-Filho, B. S. et al. Modelling conservation in the Amazon basin. Nature 440, 520-523 (2006).

38. Flanagan, W. F., Whiteman, G. Ethics codes and MNCs as minority shareholders: the case of a bauxite mine in Brazil. In: Ethics Codes, Corporations, and the Challenge of Globalization (ed. Cragg, W.). Edward Elgar Publishing (2005).

39. IBGE. Cadastro Central de Empresas Instituto Brasileiro de Geografia e Estatística (2014).

40. IBGE. Produção Agrícola Municipal Instituto Brasileiro de Geografia e Estatística (2014).

41. IBGE. Censo Demográfico Instituto Brasileiro de Geografia e Estatística (2014)

42. IBGE. Produção da Extração Vegetal e da Silvicultura Instituto Brasileiro de Geografia e Estatística (2014).

43. Sonter, L. J., Barrett, D. J. \& Soares-Filho, B. S. Offsetting the impacts of mining to achieve no-net-loss to native vegetation. Conserv. Biol. 28, 1068-1076 (2014).

44. Sonter, L. J., Barrett, D. J., Moran, C. J. \& Soares-Filho, B. S. A land system science meta-analysis suggests we underestimate intensive land uses in land use change dynamics. J. Land Use Sci. 10, 191-204 (2013).

45. Viana, M. B. \& Bursztyn, M. A. A. Environmental regularization of mining activities in the State of Minas Gerais, Brazil. Rem-Revista Escola De Minas 63, 363-369 (2010).

46. IBGE. Biomes of Brazil. (2004)

47. Soares-Filho, B. et al. Role of Brazilian Amazon protected areas in climate change mitigation. Proc. Natl Acad. Sci. USA 107, 10821-10826 (2010).

48. Nepstad, D. C., Stickler, C. M., Filho, B. S. \& Merry, F. Interactions among Amazon land use, forests and climate: prospects for a near-term forest tipping point. Phil. Trans. R. Soc. B Biol. Sci. 363, 1737-1746 (2008).

49. StataCorp. Stata Statistical Software: Release 14. College Station, TX: StataCorp LP (2015).

50. Ferraro, P. J. et al. Estimating the impacts of conservation on ecosystem services and poverty by integrating modeling and evaluation. Proceedings of the National Academy of Sciences 112, 7420-7425 (2015).

\section{Acknowledgements}

We thank F. Goulart, M. Coe, J. Morrell, G. Allez, T.H. Ricketts, J. Gourevitch, C. Nicholson, and R. Rasolofoson for comments. G. Fiske and J. Gordon provided assistance with data and imagery supported by a Google Earth Engine Research Award L.J.S. is supported by USDA McIntire-Stennis (2014-32100-06050) and ARC Discovery Early Career Research Award (DE170100684). G.L.G. is supported in part by NSF (1257944). B.S.S.F. is supported by Conselho Nacional de Desenvolvimento Científico e Tecnológico and The Humboldt Foundation.

\section{Author contributions}

L.J.S., D.H., G.L.G., and B.S.S.-F. collected data. L.J.S. and D.H. analyzed data. L.J.S., D H., D.J.B., G.L.G., C.J.M., and B.S.S.-F. wrote the paper.

\section{Additional information}

Supplementary Information accompanies this paper at doi:10.1038/s41467-017-00557-w.

Competing interests: The authors declare no competing financial interests.

Reprints and permission information is available online at http://npg.nature.com/ reprintsandpermissions/

Publisher's note: Springer Nature remains neutral with regard to jurisdictional claims in published maps and institutional affiliations.

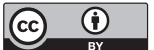

Open Access This article is licensed under a Creative Commons Attribution 4.0 International License, which permits use, sharing, adaptation, distribution and reproduction in any medium or format, as long as you give appropriate credit to the original author(s) and the source, provide a link to the Creative Commons license, and indicate if changes were made. The images or other third party material in this article are included in the article's Creative Commons license, unless indicated otherwise in a credit line to the material. If material is not included in the article's Creative Commons license and your intended use is not permitted by statutory regulation or exceeds the permitted use, you will need to obtain permission directly from the copyright holder. To view a copy of this license, visit http://creativecommons.org/ licenses/by/4.0/.

(C) The Author(s) 2017 